\title{
Mandated Shutdowns, the Ratchet Effect, and The Barstool Fund
}

\author{
JEFFREY CARROLL \\ University of Virginia
}

\begin{abstract}
Perhaps the most contentious part of the response to the Covid19 pandemic has been the decision by governments to mandate-or effectively mandate-the shutdown of certain businesses. The justification for doing so is broadly consequentialist. The public health costs of not shutting down are so great that potential benefits from allowing businesses to open are dwarfed. Operating within this consequentialist framework, this paper identifies an underappreciated set of social costs that are a product of the present public policy that pairs mandated shutdowns with government subsidies. Such policy is prone to being an instance of what Robert Higgs calls the ratchet effect. Given that ratchets tend to be both costly and sticky, it is best to avoid allowing them to come into existence. This paper identifies a way of circumventing this particular ratchet; namely, by replacing governmental subsidies with support from private charitable funds like The Barstool Fund.
\end{abstract}

Keywords: consequentialism, pandemic, Robert Higgs, ratchet effect, shutdowns

JEL Classification: D7, H11, H2, H51, H84, I1

\section{INTRODUCTION}

One of the most controversial aspects of the response to the Covid-19 pandemic has been the decision by governments to mandate-or to enact stay at home orders that effectively mandate-the shutdown of certain businesses deemed high-risk for transmission of the virus. Such businesses include restaurants, bars, gyms, movie theaters, casinos, museums, and libraries, amongst others. The rationale given for doing so is consequentialist: the costs resulting from further spreading the disease 
outweigh the benefits from allowing business owners to decide to operate as they best see fit. ${ }^{1}$

But, public policy of this sort has detrimental effects on the businesses, business owners, and employees. These effects are particularly pronounced on small businesses. ${ }^{2}$ Requiring that a small business closeor effectively close by, say, prohibiting indoor dining-leads to employees being laid off or fired. In the worst cases, the loss of revenue necessitates that some businesses close for good.

Many proponents of shutdowns find this consequence unacceptable. In the United States, the proponents' solution is to provide governmental aid to the businesses in the form of PPP loans and to the out-of-work employees in the form of stimulus checks. However, if the shutdown persists sufficiently long, then the aid to both the businesses and the individuals will run out and another round of aid will need to be administered. For said proponents, such an ongoing cycle can be (indeed, needs to be) justified until the pandemic ends.

Yet, if we are consequentializing (as the given rationale suggests we are), this is a very costly route to go. One cannot consider only the nearterm costs of the policy. Both the near-term and long-term costs of taking decision-making authority out of the hands of private citizens need to be factored into the calculus. ${ }^{3}$

This paper focuses on the cumulative costs that result from the government mandating (including effectively mandating) a shutdown. ${ }^{4}$ In particular, it identifies the public policy response of shutting down businesses and subsequently using governmental aid to keep the affected businesses and individuals afloat as an instance of what Robert Higgs (1987) calls the ratchet effect. Section II describes the ratchet effect. Section III, drawing on the work of Nathan Goodman, Christopher Coyne, and

\footnotetext{
${ }^{1}$ I do not commit to consequentialist or utilitarian public policy. My concern is with what policy conclusions follow if we embrace the broadly consequentialist and utilitarian framework that is used in popular discourse to justify mandatory shutdowns. For a thorough defense of utilitarianism as the proper policy lens, see Goodin (1995).

${ }^{2}$ This is not to say that it does not hurt larger businesses and corporations. But large chains like Chipotle and Dominoes have done quite well during the pandemic because they have the capital and infrastructure to more easily and effectively transition to being fully to-go and delivery establishments than, say, your favorite local Mexican restaurant or hometown pizza place.

${ }^{3}$ This essay focuses on the costs created by the pandemic public policy. For an excellent essay on why the costs would actually be lower in the absence of governmental intervention, see Leeson and Rouanet (2021).

${ }^{4}$ For more on hidden costs, see Bastiat ([1964] 1995). Relatedly, for a discussion of the complex implications of pandemic public policy on gender equality, see Alon et al. (2020).
} 
Abigail Devereaux (2020) as well as the related work of Coyne and Yatsyshina (2020), makes the case that the pandemic policy is prone to becoming a ratchet. Section IV considers the normative implications of a ratchet within a broadly consequentialist framework and states why it is worth taking steps to avoid this outcome. At the conclusion of Section IV, one may believe that a choice must be made between two undesirable alternatives: either opening society and accepting the costs associated with the amplified spread of the virus, or closing society and accepting the costs involved with the ratchet. Fortunately, this is a false dichotomy. Section V looks at a way of avoiding the ratchet; specifically, by relying on private, non-governmental agents to voluntarily support the shutdown businesses and out-of-work employees. The example of The Barstool Fund is considered and the reasons for opting for a private initiative like it over governmental aid, whenever possible, is discussed.

\section{THE RATCHET EFFECT}

In Crisis and Leviathan, Robert Higgs (1987) makes the case that much of the growth of government is explicable in terms of a pattern of crisis and response. Following a crisis, government is larger than it would have been had the crisis not occurred (though not as large as during the crisis). Crises are a sort of 'ratchet' that propel the expansion of government forward indefinitely.

But in what respect is it larger? That is, how is the size of government measured? The way to measure the size of government, says Higgs, is in terms of how much authority it has, not in terms of activity which "is secondary and derivative" $(1987,33)$. After a national emergency, the relevant sense in which government grows is in terms of the amount of authority it has over something like economic decision-making.

A logical next question is: Why does governmental authority expand? Part of this expansion is a result "of the 'hard residues' of crisis-spawned institutions (for example, administrative agencies and legal precedents)" (Higgs 1987, 58-59). Once an institution exists, it is hard to get rid of it in its entirety. Another part is a result of the shift in ideology following a crisis as "the events of the crisis created new understandings of and new attitudes toward governmental action" (Higgs 1987, 59). In short, people, in some sense, want the emergent institutions.

Still, an account of how the ratchet effect occurs is owed. Higgs explains it in the form of a five-stage sequence: (1) pre-crisis normality; (2) expansion; (3) maturity; (4) retrenchment; and (5) post-crisis normality 
(Higgs 1987, 60). The narrative underlying this progression of stages goes as follows. There is a base rate at which government is expanding. Then, a crisis ensues resulting in government growing at a much higher rate because "an insistent but ill-defined public [demands] that the government 'do something' about the crisis" (Higgs 1987, 73). But doing something is costly and no one (or no institution) wants to be responsible for said costs. So, government "takes steps to conceal the true costs" by substituting "a (cost-hiding) command-and-control system of resource allocation for the (cost-revealing) market system" (Higgs 1987, 73). After this expansion levels off (that is, reaches maturity), then it retrenches, but to a level that is higher than it would have been had the crisis not occurred because some of the emergent apparatus persists. Some of the aforementioned 'residue' remains. This residue also makes it easier for additional expansions in the future.

The aim of the next section is to provide reason to believe that the public policy response to the Covid-19 pandemic, particularly as it has been rolled out in places like the United States, is prone to following the pattern of stages identified by Higgs in his articulation of the ratchet effect.

\section{PANDEMic Public Policy as an Instance of the RAtchet EFFECT}

There are numerous examples of governmental growth following infectious disease crises. One example is segregation in Cape Town, South Africa that was, in part, a response to the bubonic plague, while another is the use of precedent from a legal case concerning compulsory vaccination for smallpox to justify a ruling for non-volitional sterilization. ${ }^{5}$ Is the public policy response to the Covid-19 pandemic-specifically, the part involving the mandated shutdowns of businesses and the subsequent governmental aid-susceptible to being another? ${ }^{6}$

For the answer to be yes, it needs to be the case that (i) expansion occurs in response to the mandated shutdowns and (ii) retrenchment leaves residue that makes the size of government larger than it would have been had the pandemic not occurred. The expansion of government in other areas has been documented (e.g. Habeeshian and McDade 2020; Kallingal 2020; Neil 2020; Speri 2020; Tuccille 2020). The germane

\footnotetext{
${ }^{5}$ A more thorough discussion of these examples can be found in Goodman, Coyne, and Devereaux (2020).

${ }^{6}$ Popular discussions of the policy response to the Covid-19 pandemic as an instance of the ratchet effect are available, such as Rozmajzl (2020) and Goodwin (2020).
} 
challenge is to outline the propulsion mechanism for this domain-specific ratchet.

Fortunately, the logic of this particular ratchet is not too mysterious or difficult to understand. Individuals are prohibited from working. Meanwhile, the need to make a living does not go away. Likewise, small businesses are prohibited from opening. Meanwhile, the need to make a profit does not go away. So, both individuals and small businesses need to be exogenously supported. This support comes from government. Stimulus checks to individuals and PPP loans to businesses are used to keep both afloat. Yet, as the pandemic persists and the decision to mandate the closure of certain businesses continues, the initial support gets exhausted and additional support becomes necessary. Government must then distribute a new round of support. This cycle repeats, presumptively, until the pandemic ends-and it is unknown when that will be.

The underlying logic makes for an indefinite cycle of expansion. Once the pandemic is reined in, the shutdown orders are able to be lifted. This means that individuals and businesses can resume normal operation. But it does not mean that all the governmental apparatus instantaneously disappears. Residue remains. This residue may be in the form of new governmental agencies persisting or previously existing agencies becoming bloated. Additional staff may need to be hired to adequately rollout the aid distribution. The addition or expansion of these agencies as well as the personnel staffing them are a social cost, albeit a dispersed one. With each successive round of governmental aid, the social costs increase as does the overall cost-trajectory as a result of additional excessive residue remaining.

Moreover, there are potentially even more social costs in the form of interventions in the future that are, at least partially, parasitic on the present policy response to the Covid-19 pandemic. The ideological shift and the presence of the residue, together, increase the potential for future interventions that may themselves be socially costly.

\section{Consequentialism, Costs, AND the PANDEmic Policy Ratchet}

Having made the case that this policy response is an instance of Higgs's ratchet, it is now time to state the case why this is undesirable in normative terms. One mode of critique would be to challenge the policy response from the vantage point of an alternative moral theory (say, a deontological one that finds the shutdown unjustifiable because of its restriction on individual rights). I believe a more effective critique is one 
that operates within the same broadly consequentialist framework that proponents of the shutdown defend. The specific justification seems to be that the net costs of mandating a shutdown is lower than the net costs of allowing these industries to proceed unfettered. The underlying supposition is that certain types of businesses are sites of significant transmission of the virus and the consequences of transmission are decisively costly.

I in no way doubt that there would be significant public health costs involved in allowing these businesses to operate without restriction. ${ }^{7}$ But I also believe that the costs resulting from the implementation of a mandatory shutdown are under-calculated. To be clear, I do not claim to show that the costs of not shutting down are less than the costs of shutting down. Rather, I merely seek to show that costs of not shutting down have been under-calculated in the comparative analysis. This is because the long-term costs of the ratchet effect are not being factored in. The nearterm costs, such as the loss of work for individuals and the significant debts incurred by businesses, have been well-rehearsed. But there are longer-term social costs such as those resulting from each successive round of stimulus and from the institutional residue left as a result of this particular public policy. And these longer-term costs have not been adequately considered. ${ }^{8}$

What are these longer-term costs? In their paper "Pandemic Police States", Coyne and Yatsyshina (2020) catalog costly expansions that may linger. Using Coyne and Yatsyshina's analysis as a point of departure, I propose the following three general categories under which residual costs may fall for this domain: publicizing, enforcing, and punishing. First, government must make it known that a shutdown will be occurring. This requires publicizing the rules which will be the responsibility of someone(s) or some institution(s). Second, government must enforce the shutdown. This involves both monitoring and administering. Governmental actors are needed to scout out which parties are failing to comply with the shutdown and to ticket those in violation. Third, government must hold rulebreakers accountable. There needs to be a set of governmental

\footnotetext{
${ }^{7}$ There also important health costs that are more personal from shutting down. See Mulligan (2020).

${ }^{8}$ There are also prospective costs from future interventions that are made possible by the present policy response. While I will not discuss this in detail, my argument is only strengthened to the extent that such interventions are costly as a result. Thank you to an anonymous reviewer for prompting this point.
} 
representatives that collect the debts incurred by the violators or seek further punishment for those that refuse to pay. ${ }^{9}$

It is far from obvious that all the additional actors needed by government to perform these tasks will be relieved of their roles after they are completed. More likely is that many will remain on payroll or be reassigned to a different division, thereby, expanding the size and cost of government (as well as potentially facilitating future interventions). These long-term costs can continue to accrue (perhaps, indefinitely?) in a way that limited-term public health costs do not.

\section{ReCTIFYING THE RATCHET: THE BARSTOOL Fund AS CASE STUDY}

At this point, one may plausibly think that consequentialist public policy is between a rock and a hard place. Either mandate a shutdown of businesses for the sake of containing Covid-19 while supporting those impacted by providing governmental aid-accepting the costs of the impending ratchet, or allowing businesses to open so that the impending ratchet can be avoided-accepting the public health costs of further spread of the virus. Neither option seems very appealing.

Fortunately, this is a false dichotomy. One needn't choose between these two options. There already exists a third way as evidenced by The Barstool Fund. At the time of this writing, the comedy-sports media company Barstool Sports has raised nearly 40 million dollars from over 200,000 donors in order to be able to support over 300 small businesses for the remainder of the pandemic. Its founder, Dave Portnoy, in concert with Liz Gonzalez, an employee of the company, screened through applications and allocated funds to small businesses impacted by the policy response to the pandemic. If a business receives funding, it is sufficient to get them through until the relevant governmental restrictions are lifted.

Thus, the third way is that if small businesses are not permitted to remain open, then private funds can support them. Having the support come from private funds like The Barstool Fund is preferable to support that comes from government because it prevents 'residue' being left behind in the form of bloated governmental agencies. This is because the costs are internalized by the private company. In this particular case, the operation of the fund is being done by people who are already employees of the company. So, there is no additional overhead or bloat. Furthermore,

\footnotetext{
${ }^{9}$ Like was the case with the Atilis Gym, ran by Ian Smith, in New Jersey (Bellano 2021).
} 
in virtue of the support being provided by donations to a private fund, the support comes from wholly voluntary sources and sidesteps thorny issues that arise for governmental aid that comes from taxation or increasing the national debt.

Of course, there are limits to the extent to which private charitable funds can support small businesses. There is both a conceptual and an empirical point to address. The conceptual point is that it should not be a strike against a private alternative that it cannot support all small businesses because, surely and hopefully, there are limits to what government can support, as well. The relevant comparison is not between a limited charitable fund and an unlimited government. Such a comparison makes it seem as if the support provided by government comes deus ex machina, when it actually is a dispersed social cost. It is just one that is (perhaps, purposefully) hard to precisely define. ${ }^{10}$ Such a comparison is equivalent to comparing nonideal capitalism with ideal socialism. ${ }^{11}$ One must compare like-to-like. This means that while charitable funds are limited, the full costs of unbounded governmental support must be considered. Doing so makes the latter decidedly more difficult to justify in consequentialist terms. Hence, there is a compelling pro tanto case to be made that it is less costly for private funds to support businesses and individuals than it is for government to provide blanket aid.

A plausible conclusion would be that private funds, not government, should support businesses and individuals impacted by a mandated shutdown. But this may bump up against empirical realities. The number and power of private funds will vary by country. ${ }^{12}$ Those with less of a charitable tradition may not have anywhere near the private support needed to support the businesses that are forced to close. What follows from this? It is not that that empirical realities necessitate that aid come from government, since private funds are too limited. Rather, the inference that should be drawn is that private funds, whenever possible, should support those impacted by the shutdown. While private funds may not be able to support all in need, it is preferable to have private support when possible.

A relevant corollary is that the proliferation of private funds would be a superior alternative to resorting to government aid. Put differently,

\footnotetext{
${ }^{10}$ Higgs (1987) offers an explanatory logic as to why the cost-concealing apparatus of government is opted for over the cost-revealing mechanisms of the market.

${ }^{11}$ Brennan (2014) and Freiman (2017) charge Cohen (2009) with making such an unfair comparison. The general point that behavioral asymmetry needs to be assumed in comparative analysis is found in Buchanan and Brennan (2000).

${ }^{12}$ Thank you to the editors for raising this point.
} 
public policy should be looking at ways to incentivize increasing the number and expanding the size of private funds. The solution in a slogan is 'more private funds, not more government'. An interesting implication worth further exploration is that in cases where private funds are insufficient to support those in need, it would be preferable to mandate charity rather than levy a tax as it eliminates the tendency for lingering, unnecessary residue, and reduces the propensity for future interventions. ${ }^{13}$

The upshot of this section is that one is not forced to choose between increased public health costs that result from a full-fledged opening and increased economic costs that result from restrictions on businesses. ${ }^{14}$ One who thinks that the public health costs of opening are sufficient to justify mandating a shutdown should not couple that conviction with governmental aid. Doing so creates the condition for a thriving ratchet. Given the difficulty of rectifying a ratchet once it emerges, it is best to avoid bringing it into existence in the first place. Hence, private aid is preferable and public policy should seek ways to incentivize it and expand its extent so that governmental aid does not need to be resorted to or is resorted to as little as possible.

\section{CONCLUSION}

This paper has made the case that the policy response to the pandemic is an instance of the ratchet effect. Within a consequentialist policy frame, ratchets are problematic because they lead to increased costs over time. But there are emerging alternatives that offer the potential to break the ratchet or prevent one from emerging. Voluntary charitable funds like The Barstool Fund have the potential to support individuals and small businesses during the shutdown without the potential for the problematic institutional bloat that arises with governmental support. In short, private funds can offer the same type of benefits, but with a relative reduction in costs. Though, of course, private funds will be unable to support all in need when government mandates a shutdown. Nonetheless, complete support from private funds can be the aspirational goal. ${ }^{15}$ Hence, one way

\footnotetext{
${ }^{13}$ I lack the space to offer a full-fledged defense of this implication here, but believe public policy would benefit from a deeper comparative analysis between mandated charity, on the one hand, and tax and redistribution, on the other.

${ }^{14}$ There are other middle options, some of which may be worth exploring. My aim in this paper is not to settle on a precise positive proposal. Rather, it is to make the case that costs resulting from shutdowns are far more extensive and tend to accrue much farther into the future than is often recognized. Thanks to Greg Robson for a helpful discussion on this point.

${ }^{15}$ On aspirational goals, see Estlund (2014, 2020).
} 
of understanding the argument of this paper is that if we are committed to a mandatory shutdown (which I have reservations about), then if we are committed to supporting those out of work as a result of the shutdown (which, when the prior antecedent obtains, I have reservations about), then the support should come by way of private charitable funds like The Barstool Fund because it reduces the net social costs by reducing the institutional bloat of governmental agencies over time.

\section{REFERENCES}

Alon, Titan, Matthias Doepke, Jane Olmstead-Rumsey, and Michèle Tertilt. 2020. "The Impact of COVID-19 on Gender Equality.” NBER Working Paper No. 26947. National Bureau of Economic Research, Cambridge, MA.

Bastiat, Frédéric. (1964) 1995. Selected Essays on Political Economy. Edited by George B. de Huszar. Translated by Seymour Cain. Irvington-on-Hudson, NY: Foundation for Economic Education.

Bellano, Anthony. 2021. "Controversial NJ Gym Owners Say State Has Seized \$165K in Assets.” Patch, January 15, 2021. https://patch.com/new-jersey/haddon/controversial-nj-gym-owners-say-state-has-seized-165k-assets.

Brennan, Jason. 2014. Why Not Capitalism? New York, NY: Routledge.

Buchanan, James M., and Geoffrey Brennan. 2000. The Collected Works of James M. Buchanan. Volume 10. The Reason of Rules: Constitutional Political Economy. Indianapolis, IN: Liberty Fund.

Cohen, Gerald A. 2009. Why Not Socialism? Princeton, NJ: Princeton University Press.

Coyne, Christopher J., and Yuliya Yatsyshina. 2020. "Pandemic Police States." Peace Economics, Peace Science and Public Policy 26 (3): 20200021.

Estlund, David. 2014. "Utopophobia.” Philosophy \& Public Affairs 42 (2): 113-134.

Estlund, David. 2020. Utopophobia: On the Limits (If Any) of Political Philosophy. Princeton, NJ: Princeton University Press.

Freiman, Christopher. 2017. Unequivocal Justice. New York, NY: Routledge.

Goodin, Robert E. 1995. Utilitarianism as a Public Philosophy. Cambridge: Cambridge University Press.

Goodman, Nathan P., Christopher J. Coyne, and Abigail Devereaux. 2020. "Infectious Diseases and Government Growth." GMU Working Paper in Economics No. 20-40. George Mason University, Fairfax, VA.

Goodwin, Matthew. 2020. "COVID-19 Will Reshape Our Relationship with the State." Chatham House, May 12, 2020. https://www.chathamhouse.org/2020/05/covid-19will-reshape-our-relationship-state.

Habeeshian, Sareen, and Mary Beth McDade. 2020. "Mayor Garcetti Announces Water and Power Will Be Shut off for Nonessential L.A. Businesses That Don't Close.” KTLA, March 25, 2020. https://ktla.com/news/coronavirus/mayor-garcetti-expected-tohold-daily-briefing-on-l-a- s-covid-19-response/.

Higgs, Robert. 1987. Crisis and Leviathan: Critical Episodes in the Growth of American Government. New York, NY: Oxford University Press.

Kallingal, Mallika. 2020. "Ankle Monitors Ordered for Louisville, Kentucky Residents Exposed to Covid-19 Who Refuse to Stay Home." CNN, April 3, 2020. 
https://edition.cnn.com/2020/04/03/us/kentucky-coronavirus-residents-anklemonitors-trnd/index.html.

Leeson, Peter T., and Louis Rouanet. 2021. "Externality and COVID-19." Southern Economic Journal 87 (4): 1107-1118.

Mulligan, Casey B. 2020. "Deaths of Despair and the Incidence of Excess Mortality in 2020.” NBER Working Paper No. 28303. National Bureau of Economic Research, Cambridge, MA.

Neil, Denise. 2020. "You're Not a Snitch If You Report Those Defying Stay-at-Home Order, Local Officials Say." The Wichita Eagle, April 5, 2020. https://www.kansas.com/news/coronavirus/article241743631.html.

Rozmajzl, Anthony. 2020. "Confronting the Leviathan of the COVID-19 Crisis." Foundation for Economic Education, April 16, 2020. https://fee.org/articles/confrontingthe-leviathan-of-the-covid-19-crisis/.

Speri, Alice. 2020. "NYPD's Aggressive Policing Risks Spreading the Coronavirus." The Intercept, April 3, 2020. https://theintercept.com/2020/04/03/nypd-social-distancing-arrests-coronavirus/.

Tuccille, J. D. 2020. "The Surveillance State Thrives During the Pandemic." Reason, April 10, 2020. https://reason.com/2020/04/10/the-surveillance-state-thrives-duringthe-pandemic/.

Jeffrey Carroll is a PhD candidate in Philosophy at the University of Virginia. His research is in social and political philosophy and PPE. More specifically, he often works on methodological issues concerning justice-theorizing and democracy. His published work appears in The Journal of Politics, Social Theory and Practice, HEC Forum, and The Independent Review. Contact e-mail: <jmcarroll422@gmail.com> 